\title{
Bringing Life from Death: Is There a Good Justification for Posthumous Cloning?
}

\section{Daniel Sperling}

Senior Lecturer in Bioethics, Hebrew University of Jerusalem, Hebrew University of Jerusalem, Israel

\begin{abstract}
Although speculative and ethically controversial, cloning a dead person may be scientifically possible as more experimentation on dead animals continues. The article proposes that posthumous cloning may be justifiable in cases where the dead expressed their wishes to be cloned, or when next-of-kin seek to extend the impact of the dead on the living. Under this argument, justification for posthumous cloning does not stem from the concept of reproductive autonomy but from one's interest in the recognition of one's symbolic existence. Hence, posthumous cloning promotes the recognition in the symbolic existence of the dead (through the cloned), and indirectly enriches the social image, sense of identity and relational autonomy of the cloned. Seen in this way, cloning should not be regarded as an act which violates human dignity or that instrumentalizes the cloned.

However, the article suggests the following limitation for posthumous cloning: that the nature of the relationship between the cloned and the persons preserving the symbolic existence of the dead should be the same as prior to cloning. Such a limitation would make posthumous cloning an exceptional phenomenon. Regardless of its prevalence, posthumous cloning makes us rethink our general moral opinions on cloning and the ethics of death.
\end{abstract}

Consider the following scenarios: a couple who loses a late-term pregnancy at a point when they can no longer conceive wishes to clone the dead fetus to obtain a child who would be genetically related to both of them; A family seeks to clone their single son who died in a car accident; A grieving woman in her 40s wants to bring back her dead father as her own baby. These scenarios raise the question of whether, and if so in what circumstance, is it justifiable to clone the dead. Although these scenarios are fruits of imagination, a request to clone a ten-month old baby who died in the hospital following a minor operation has already been reported in the literature [1].

Since the creation of Dolly in 1996, many types of animals have been cloned, and although some of these animals have been cloned from dead tissues ever since, only recently did Japanese researchers report on cloning mice from frozen corpses of mice which died 16 years prior to cloning [2]. Their technique not only supported the scientific ability of cloning the recently dead but has been extended to cases of death occurring many years ago, increasing the possibility to clone dead corpses which have been cryopreserved and encouraging DNA storage for posthumous clone.

Cloning consists of two different processes: Pre-implantation embryo splitting leading to monozygotic (or more) identical siblings and Cell Nuclear Replacement (CNR) or Cell Nuclear Transfer (CNT) under which the nucleus of a donor cell taken from embryonic, fetal or adult cells is introduced into an egg, and following appropriate stimulation developed and is implanted in a viable womb to develop to term. Once split, one of the two or more siblings can be frozen and implanted when the first dies. Under posthumous cloning, the nucleus of a dead child or adult can be replaced (or transferred) in an embryo. The clone will be the twin sibling of the dead nucleus donor and the genetic child of the donor's own parents. Yet, it will not be genetically identical to the dead since it will inherit the mitochondrial DNA from the oocyte donor. Because of this fact and due to the difference in moment of birth and expected moment of death of the nucleus donor and the cloned [3], the clone's personal identity would not be identical to the dead [4]. Hence, it will not serve as a means to satisfy the interests of the previously dead or his or her parents but will have a worth of its own.
Although human reproductive cloning cannot be applied at present it may be of interest in various scenarios once it becomes safe and its scientific mechanism is approved. Couples may choose cloning instead of an anonymous sperm, egg or embryo donation. Reproductive cloning may also be of interest to couples who are at high risk of having offspring with a genetic disease or for the creation of a child who will serve as an organ donor to his or her sibling [5]. Other than these practical uses, reproductive cloning can be regarded as part of human progress that could lead to a new type of genetic immortality [6]. However, the reproductive applications of CNR/CNT are currently speculative and necessitate some degree of experimentation on humans - a highly unacceptable practice. Furthermore, one needs to overcome the problems of scarcity of oocytes which will be available for cloning. In countries where commerce in oocytes is forbidden or where their donation is restricted for reproductive use, shortage of oocytes is a serious challenge to cloning. As mentioned above, there are also safety issues that still need to be resolved [7]. If the donor has died as a result of illness, it may be that the somatic cell from which the nucleus is donated may carry the genetic defect responsible for that illness, that the membrane and the DNA had broken, or that ice crystals caused by freezing the cells taken from a corpse destroy the DNA so that cloning would be impractical or unsuccessful. Above all, the deliberate cloning of human beings, dead or alive, is still ethically unacceptable and legally prohibited in many Western countries [8]. It is argued that cloning violates the laws of nature or the laws of God; that it violates the individuality of the human being; and that it violates the autonomy

Corresponding author: Daniel Sperling, Senior Lecturer in Bioethics, Hebrew University of Jerusalem, Hebrew University of Jerusalem, Israel, Tel: 972-2 5880028/ 972-2-6757284; Fax: 972-2-6435083; E-mail: dsperling@mscc.huji.ac.il

Received July 01, 2011; Accepted July 22, 2011; Published August 10, 2011

Citation: Sperling D (2011) Bringing Life from Death: Is There a Good Justification for Posthumous Cloning? J Clinic Res Bioeth S1:001. doi:10.4172/2155-9627.S1001

Copyright: @ 2011 Sperling D. This is an open-access article distributed under the terms of the Creative Commons Attribution License, which permits unrestricted use, distribution, and reproduction in any medium, provided the original author and source are credited. 
of the human being by reducing it to a commodity [9]. The primary arguments supporting the legal ban on human reproductive cloning are summarized by Annas and colleagues and are as follows:

"These interventions [cloning and inheritable genetic alterations] would require massive dangerous and unethical human experimentation, that cloning would inevitably be bad for the resulting children by restricting their right to an 'open future', that cloning would lead to a new eugenics movement for 'designer children' (because if an individual could select the entire genome of their future child, it would seem impossible to prohibit individuals from choosing one or more specific genetic characteristics of their future children), and that it would likely lead to the creation of a new species or subspecies of humans, sometimes called 'the posthuman" [10].

Overall, cloning is viewed as revolting, repellent, unnatural and disgusting [11]. Indeed, some argue that the real basis for the legal ban on reproductive cloning is repugnance at the very idea of cloning [12].

Yet, the case of posthumous cloning may serve as an exception to the ban on human reproductive cloning. This is because other than attributing genes the characterization of "blood relations" and the imperative of spreading all of our genes to secure our survival, one of the many dimensions or interests we have in cloning concerns immortality [13]. The wish to avoid death by offering, for example extensive and futile life-saving treatments, our desire to live forever and postpone our aging and decay of our bodies, through various procedures and drugs, or our beliefs in revival when effective treatments become available through thawing our cryopreserved bodies, may support the idea that survival of our own or beloved ones' genes enables us to combat death in a way that makes us feel living. It may be argued that posthumous cloning may be justifiable in cases where the dead expressed their wishes to be cloned, or when next-of-kin seek to extend the impact of the dead on the living. Under this argument, justification for posthumous cloning does not stem from the concept of reproductive autonomy or procreative liberty, whatever that may be [14], but from one's interest in the recognition of one's symbolic existence which I have argued elsewhere [15]. Such an interest stands for one's nonmaterial abstract existence or material existence usually taking place in the minds, thoughts, and language of other existing (and in our case, genetically similar) creatures, or in the actions (cloning), possessions (in the tissues to be cloned posthumously) and the like of the deceased. It reflects the idea that a person's individual image and legacy and recollections of them by others consist of more than the visual images of the flourishing or deteriorating body of a person. Through the act of posthumous cloning, the interest in the recognition of one's symbolic existence relating to the dead person and held by the Human Subject whose existence persists over time [16], is protected and fulfilled to the full.

If one accepts the argument from symbolic existence, cloning should not be regarded as an act which violates human dignity or that instrumentalizes the cloned. To the contrary, under such an understanding posthumous cloning promotes the recognition in the symbolic existence of the dead (through the cloned), and indirectly enriches the social image, sense of identity and relational autonomy of the cloned, yet allowing them to develop their unique individuality. For the purposes argued above, posthumous cloning may also not serve parents as a means to live vicariously through their children, and it is anticipated that it will not lead to feels of repugnance or revolt having emerged from the interests of the dead and not from those who initiate and take a role in the reproductive cloning [17]. Finally, posthumous cloning deriving from one's interest in the recognition of his or her symbolic existence does not create a child with a confused or ambiguous family, since those who commission the cloning continue to demonstrate their role as parents (to the cloned) [18], and there will not be a case in which a number of family members would be parents in different senses [19], since the genetic parents of the cloned are also his or her social and legal parents [20].

However, it will be argued that for posthumous cloning to be justified, the nature of the relationship between the cloned and the persons preserving the symbolic existence of the dead should be the same as prior to cloning. This is because the whole idea of symbolic existence is based on Mead's symbolic interactionist view, holding that the self originates in a social context and becomes aware of itself through communication with others. A different relationship with the cloned alters the social web within which the cloned may be expected to fulfill or reflect the symbolic existence of the dead. Another limitation for posthumous cloning would be to restrict its justifiability to cases of unexpected or fatal deaths, or otherwise to deaths resulting from a condition for which the deceased did not have control. Restricting posthumous cloning to such situations will make it a relatively rare phenomenon, and allow nature take its course in the vast majority of cases. It follows that while in the first scenario above, due to its moral status the dead fetus cannot be claimed to have a full protected interest in the recognition of its symbolic existence, in the third scenario, the grieving mother seeks to change her relationship with her dead father and act as if she were his mother, thereby reshaping his symbolic existence and perhaps also reinventing new contents for such existence, the latter of which derive exclusively from a mother-child relationship. Thus, only in second scenario above, may posthumous cloning be justified.

The achievability to clone the dead will continue to occupy us as we make scientific progress in this direction. It should, therefore make us rethink our general moral opinions on cloning and the ethics of death. Moreover, posthumous cloning raises a fascinating question on our ability to produce life from death. This is not a novel question [21], although it is examined by a new and more complicated technology. After all, this is what bioethics is all about although it is examined by a new and more complicated technology. After all, this is what bioethics is all about.

\section{References}

1. D. Cohen Cloning, $2^{\text {nd }}$ ed. Brookfield, CT: Twenty-First Century Books: 2002 pp. 119-120; M. Talbot, "A Desire to Duplicate" The New York Times Magazine, February 4, 2001. pp. 62-69. For scientific attempts towards cloning a dead human being see: First Steps in Cloning from Dead, Chinadaily, August 31 2004

2. A. Taher, Briefing: Cloning the Dead: A Risky Kiss of Life The Sunday Times $(9 / 11 / 08)$.

3. It is argued in the scientific literature that the cloned may not develop and age in the same way as the nucleus donor.

4. Kamm FM (2000-2001) Cloning and Harm to Offspring. N Y Univ J Legis Public Policy 4: 65-76.

5. Robertson JA (1998) Human Cloning and the Challenge of Regulation N Eng J Med 339: 119-122

6. Annas GJ, Andrews LB, Isasi RM (2002) Protecting the Endangered Human Toward an International Treaty Prohibiting Cloning and Inheritable. Am J Law Med 28: 151-178.

7. National Research Council, Scientific and Medical Aspects of Human Reproductive Cloning (2002)

8. In some countries, like Israel, the legal prohibition against human cloning is set by a moratorium. 
Citation: Sperling D (2011) Bringing Life from Death: Is There a Good Justification for Posthumous Cloning? J Clinic Res Bioeth S1:001. doi:10.4172/2155-9627.S1-001

Page 3 of 3

9. National Bioethics Advisory Commission, Cloning Human Beings: Report and Recommendations of the National Bioethics Advisory Commission Rockville, MD: 1997; R. Altchuler, Human Cloning Revisited: Ethical Debate in the Technological Worldview (2009) Biomedical Law \& Ethics 3: 177-195.

10. Annas et al. supra note 6 at 161-162.

11. Gillon R (1999) Human reproductive cloning - a look at the arguments against it and a rejection of most of them. J R Soc Med 92: 3-12.

12. Goldberg S (2004) Cloning Matters: How Lawrence v. Texas Protects Therapeutic Research. Yale J Health Policy Law Ethics 4: 305-318.

13. Harris J (2004) On Cloning London \& NY: Routledge.

14. Robertson J (2003) Procreative Reproduction in the Era of Genomics. American Journal of Law \& Medicine 29: 439-387; Sperling D. 2011. 'Male and Female He Created Them': Procreative Liberty, Its Conceptual Deficiencies and the Legal Right to Access Fertility Care of Males. International Journal of Law in Context vol. 7(3) (forthcoming).
15. D. Sperling. Posthumous Interests: Legal and Ethical Perspectives Cambridge \& NY: Cambridge University Press: 2008

16. Sperling, 2008, Ibid.

17. Kass LR (1997) The Wisdom of Repugnance: Why We Should Ban The Cloning of Humans. Valparaiso University Law Review 32: 679-705.

18. Robertson J (2000) Cloning as a Reproductive Right in G. McGee ed. The Human Cloning Debate Berkeley, CA: Berkeley Hills Books 42-57.

19. O. O'Neill. Autonomy and Trust in Bioethics Cambridge: Cambridge University Press: 2002

20. The cloned is the generic sibling and not the son or daughter of the nucleus dead donor.

21. D. Sperling. Management of Post-Mortem Pregnancy: Legal and Philosophical Aspects Aldershot: Ashgate Publishing: 2006.
This article was originally published in a special issue, Ethics: Reproductive Technologies handled by Editor(s). Dr. Stephen Napier, Villanova University, USA 